\title{
Etymological Connections Between the Ancient People of Iaones and the Tacitean Suiones
}

\section{Arduino Maiuria}

\begin{abstract}
According to Felice Vinci's revolutionary theory of the Nordic origins of the Homeric poems, the Achaeans who migrated to the Aegean Sea to found the Mycenaean civilization-whose language actually was an Ionian dialect, similar to that of Homer-were the Iaones, deriving their origin from Sweden. The Italian scholar offers significant analogies to prove his hypothesis, drawing them from several scientific disciplines, such as history (the movement appears similar to that of Varangians, who in the Middle Ages moved from Sweden to found the kingdom of Rus'), geography (the promontory of Cape Sounion, located 43 miles south-southeast of Athens, seems to be a souvenir of the same name), archaeology (the spiral shape, one of the most popular ones in the volutes of the Ionic capitals, was a common decoration also during the Nordic Bronze Age), and literature (especially a remarkable quotation taken from Plato, Critias 111e). In the author's contribution, he tries to check Felice Vinci's interpretation through a careful survey in ancient literature and linguistics, in order to verify the etymological connections between the ancient people of Iaones and the Tacitean Suiones.
\end{abstract}

Keywords

Homer, Felice Vinci, Baltic Sea, Tacitus, Pliny the Elder

The purpose of this short paper is to provide some linguistic evidence for the theory of the Nordic origin of the Homeric poems, as it has been formulated by Felice Vinci 25 years ago, and enhanced with increasingly new elements until today (Vinci 2017). One of its most recent insights (Vinci 2016: 337) concerns the identification of the Iaones, probably the Iaones quoted by Hom., Il. XIII, 685, with the Scandinavian people of the Suiones, mentioned by Tacitus in the last chapters of his Germania (44-45). According to Vinci's reconstruction, it is likely that the Achaeans, who migrated to the Aegean Sea to found the Mycenaean civilization-whose language actually was an Ionian dialect, similar to Homer's one-were the Ionians. As a result, Ionians derive their origin from Sweden. This idea goes against the prevalent opinion that justifies the Ionic basis of
Homer's language by means of its first writing during the Pisistratid tyranny, in the sixth century BC. If we follow Vinci's new lead on the investigation, the presence of the Ionic dialect inside the poems is much more important than it has been thought so far: In brief, it may be considered as a "genetic" constitution, not merely as an influence. Felice Vinci offers significant analogies to demonstrate his hypothesis. He draws this idea from several scientific disciplines, such as history, geography, archaeology, and literary sources. It is interesting to check his interpretation in the light of linguistics, in order to verify whether an

\section{aSapienza University of Rome, Italy}

\section{Correspondent Author:}

Arduino Maiuri, Piazza dei Prati degli Strozzi 31, 00195, Rome, Italy 
etymological connection between the ancient Iaones and the Tacitean Suiones provides scientific data or not.

\section{VINCI'S THEORY: ITS MOST RECENT INSIGHTS}

The first step is to illustrate the arguments provided by Vinci on this topic (Vinci 2016: 316-318). First of all, he mentions an example taken from the Medieval History, that can be resumed as follows. The Varangians were the Swedish branch of the Scandinavian Vikings. Their expansion pointed to the East to found the kingdom of Rus', while the Danes and the Norse pointed to the South and the West, respectively. Some geographic data allow us to think that the displacement of populations was a common phenomenon in the Middle Ages. Following these guidelines, we have good reasons to think that a similar phenomenon had occurred also in the Bronze Age. As a result, it cannot be excluded that also the Achaeans moved towards the Mediterranean from Sweden. Actually, according to Vinci's theory, the Ionians had settled in the central and southern parts of Sweden, specifically in the southern area of the present day region of Svealand (such conclusion derives from an analytical examination of the Catalogue of Ships and its links with the rest of the Iliad). Svealand is the Swedish region that takes its name from the Suiones mentioned by Tacitus in the Germania. Vinci's idea is that the name of Suiones is an equivalent of the Homeric Iaones. If that were the case, the Achaeans who migrated toward the Aegean Sea (thus starting the Mycenaean civilization) were properly the Ionians coming from Sweden. The parallelism with the Varangians, suggested by geographical data, may confirm this opinion, despite the time gap between these two events. Vinci also draws attention to the fact that the inhabitants of classical Athens spoke an Ionian dialect, and maybe Plato could have left some clues about the ancient Swedish counterpart of the town, especially when he observes that "the part where there is the Acropolis was very different from today's" (Critias 111e). The Italian scholar notes also that the volutes of the Ionic capitals - for example those of the Erechtheum on the Acropolis of Athens - are spirals, that is a very common decoration of the Nordic Bronze Age (as an example, some jewels of the National Museum of Copenhagen present the same feature). Further, formal coincidences probably regard the toponym Cape Sounion ("the sacred Athen's cape": Hom., Od. III, 278) or Solon, the famous Athenian legislator, whose name recalls that of the Sulones, a term referred by the Egyptian geographer Ptolemy (III, 5, 8) to the Tacitean Suiones, namely the ancient Swedes. The relationship between the world of Age of Bronze and the Swedish-Mediterranean Ionia is an interesting and intriguing perspective from which we can try to rethink the dawn of the Greek and European civilization.

\section{ANCIENT SOURCES AND MODERN INTERPRETATIONS}

These are the main points of Vinci's theory about this topic. Now let us start analyzing the ancient sources.

The Latin historian P. Cornelius Tacitus (Germ., 44, 2-3), dealing with the ancient people of the Suiones, says that:

They were situated on the Ocean itself, being powerful in ships, besides men and arms. The form of their vessels was peculiar in this respect, that a prow at either extremity acted as a forepart, always ready for running into shore. They were not worked by sails, nor had they a row of oars attached to their sides; but, as on some rivers, the apparatus of rowing was unfixed, and shifted from side to side as circumstances required. And they likewise honoured wealth, and so a single ruler holded sway with no restrictions, and with no uncertain claim to obedience. Arms were not with them, as with the other Germans, at the general disposal, but were in the charge of a keeper, who was actually a slave; for the ocean forbidded the sudden inroad of enemies, and, besides, an idle multitude of armed men was easily demoralized. And indeed it was by no means the policy of a 
monarch to place either a nobleman, a freeborn citizen, or even a freedman, at the head of an armed force.

Modern scholars focused their interest on this important source (for example, Malone 1925). While Tacitus uses here the term Suiones, we have evidence that this ethnic group is named in several other ways, such as Sueones, Sweonas, Suehans, Sviar, or Svear. These people, of Germanic origin and allocated in Scandinavia, corresponded to the Suebi (Swabians). In the past, it was a very common practice to give a country the name of the ancient Germanic people: In Italy, the name of Lombardy region derives from the name of Lombard people. Also in France, Burgundy derives from the Burgundians, while Germany owes its name to the Germans (or alternatively the Alamanni, if we consider the Spanish and French names, Alemania and Allemagne, respectively) as well as France to the Franks. The most ancient sources, such as the Norse Sagas and especially the Heimskringla, describe the Swedes as very powerful people, so that their kings boasted of descending from the god Freyr. During the Viking Age, they formed the basis of the Varangians group, that is, precisely those Vikings who moved eastward. One of the first places where they settled was the eastern Svealand, in the area of modern cities of Uppsala and Stockholm and the Gästrikaland province. Their territories, however, had soon included other provinces and nowadays the place is one of the most fertile and populous of Scandinavia. The very name of Sverige ("Sweden" in Swedish) could be the evolution of Svea rike ("the kingdom of Sueones").

Etymologies on their name are essentially three and theories about them have been conceived in the first half of the twentieth century.

The oldest hypothesis is also the most accepted (Friesen 1915; Hellquist 1922; Pokorny 1959; Bandle et al. 2002). The name Sverige could come from the root *Swe and originally it could have been an adjective, the ancient Germanic *Sweoniz ("relative", a term which emphasizes their genetic cohesion). The Gothic form would be *Swians and ancient Norse *Sweoniz.

A few years later, it was proposed (Noreen 1920: 32) that the term Suiones would be the Latinization of the ancient Germanic *Swihoniz ("[people] belonging to someone"), from the root $*_{\text {swih }}$, corresponding to the Latin reflexive possessive pronoun suus (such root is also attested in Slavic languages and is present in modern Scandinavian languages in nominal formations like svåger, "brother-in-law", and svägerska, "sister-in-law"). This form would become *Swaihans in Wulfila and Suehans in the treatise De origine actibusque Getarum by Jordanes. In ancient Norse, the form *Swehaniz is attested, then evolved in Sviar in western ancient Norse and Swear in the eastern branch. However, this etymological hypothesis, although supported by a conspicuous lexical evidence, did not get the desired success.

According to the third theory (Schagerström 1931), the word Sverige is linked with the ancient Germanic *saiwi-, i.e. "concerning the water", where *saiwi- is supposed to mean "lake", such as German See or English sea. Therefore, its derivatives *siwioniz and *swi-oniz refer to the "people from the sea". Now this theory seems to have enjoyed a special enthusiasm among scholars.

Despite the interpretations about the origin of the name are quite different, most scholars agree on the fact that the Latin Suiones, the Norse Sviar, and the Sweon(as) of ancient English refer to the same people. Even if the $n$ has disappeared in the outcome Svear/Sviar, its presence is still present in the ancient adjective Svensk, by which today the Swedes are designated in their language. That name is attested throughout the Middle Ages, with all its possible versions, including Jordanes, Snorri Sturluson, the Anglo-Saxon poem Widsith (VI-VII centuries), and the more famous epic of Beowulf (VIII-X centuries), focused on the wars fought by Sueones and Geats in the sixth century; it appears also in the translation of 
Orosius' Histories made by Alfred the Great, in the sources of the Franks, like the Annales Bertiniani, and in the learned Adam of Bremen, in the eleventh century. Concerning the most ancient texts, especially those that belong to the first imperial age of Roman History attract our interest because of their greater antiquity.

The passage of the Germania by Tacitus is commonly dated to the end of the first century AD. Another text of even greater importance appeared a few years earlier, in the Naturalis Historia of Pliny the Elder (IV, 96). This excellent polygraph discussed the still unknown size of the Scatinavia "island" (indeed, he believed that it was an island: The Scandinavian Peninsula had not yet been fully explored by the Romans, so he described it as an island). Pliny wrote that in this "island" lived the people of Hilleviones, and that they were organized in hundreds of villages and confident of being a world apart (alterum). It is this unusual witness that could throw a beam of light on the question of the reasonable etymological relationship between Suiones and Iaones.

It is noteworthy to quote also the translation of this important text (for more details see Grane 2007: 17-18):

Then we come to the nation of the Ingaevones, the first in Germany. In their country we can find an immense mountain, whose name is Sevo, not less than those of the Riphaean range, and which forms an immense gulf along the shore as far as the Promontory of the Cimbri. This gulf, which has the name of the "Codanian", is filled with islands; the most famous among which is Scatinavia, of a magnitude as yet ascertained: the only portion of it at all known is inhabited by the nation of the Hilleviones, who dwell in five hundred villages, and call it a second world: it is generally supposed that the island of Eningia is of not less magnitude.

\section{CONCLUSIONS}

A point that has been always stressed by all commentators is that the Hilleviones, in spite of their huge size (five hundred villages suggest a significant number of inhabitants), are not otherwise known to posterity. Therefore, it was ingeniously proposed by a Danish scholar, since the late nineteenth century (Schütte 1898: 931), that here a relevant misunderstanding can occur, that is an error of transcription of a copyist. In brief, the nexus of Hillevionum gente may represent the corruption of the expression Illa Suionum gente, because phonemes $u$ and $v$ practically coincide in Latin pronounciation. These reflections would increase the sense of the whole matter, because, as we have seen, in that area settled the people who Tacitus, a few years later, called Suiones, evidently according to a transliteration process that was acceptable to his contemporary Latin writers.

In the author's opinion, the hypothesis of a corruption, able of introducing and spreading the error throughout Pliny's manuscript tradition, is pretty convincing. The decisive argument is the fact that in the later periods, there is no longer trace of these mysterious Hilleviones, whereas Suiones, Sueones, and all the other forms in which the name of these people appears are frequenlty mentioned. However, what has not yet been said is that, in paleographical terms, Illa Suionum gente is not the only possible reading, but another one, equally acceptable, may be considered: Illa (in the sense of "famous", "popular", a peculiar and connotative meaning of this Latin pronoun) Ionum gente, likewise the plural of a genitive, but not of Suiones, i.e. the name that will prevail in the course of time in place of Iones, that is, instead, the original word (as confirmed by some important phonetic practices of the Greek language, showing the fall of sibilant plus labiodental initial group). A remarkable example is given from the adjective $\dot{\eta} \delta \dot{v} \varsigma$ ("sweet": the same aspiration is in the verb óv $\delta \dot{\alpha} v \omega$, "to like"), in which the group has disappeared, whereas its original presence is jointly confirmed in other Indoeuropean languages, such as Sanskrit svädu-, Latin suavis, and nowadays, English sweet.

To conclude, the linguistic clues are often historical relics of ancient eras that may give to 
modern scholars much more information than expected. It is our task to give them new light. Perhaps such an effort will not always be successful, but sometimes, its main importance lies in opening up new horizons for scientific research.

\section{References}

Bandle, O., K. Braunmüller, E. H. Jahr, A. Karker, H.-P. Naumann, U. Telemann, ... G. Widmark. 2002. The Nordic Languages: An International Handbook of the History of the North Germanic Languages. Berlin \& New York: De Gruyter.

Friesen (von), O. 1915. Verdandis småskrifter (Verdandis Pamphlets) $n r .200$. Stockholm.

Grane, T. 2007. "Did the Romans Really Know (or Care) About South Scandinavia? An Archaeological Perspective." Pp. 7-29 in Beyond the Roman Frontier: Roman Influences on the Northern Barbaricum, edited by T. Grane. Roma: Quasar.

Hellquist, E. 1922. Svensker etymologisk ordbok (Swedish Etymological Dictionary). Lund: Gleerup.

Malone, K. 1925. "The Suiones of Tacitus." The American Journal of Philology 46:170-176.
Noreen, A. 1920. "Nordens ældste folke-og stednavne" (The Oldest People and Place Names in the Nordic Countries). Fornvännen (Friend of the Past) 15:23-50.

Pokorny, J. 1959. Indogermanisches Etymologisches Woerterbuch (Indoeuropean Etymological Dictionary). Bern \& Wien: Francke.

Schagerström, A. 1931. "Sviar." Namn och Bygd (Name and District) 19:144-156.

Schütte, G. 1898. Salmonsens Konversationsleksikon (Salmonsens Conversation Lexicon) VIII. København: Brødrene Salmonsens Forlag.

Vinci, F. 2016. Homère dans la Baltique (Homer in the Baltic). Paris: Astrée.

_ 2017. "The Nordic Origins of the Iliad and Odyssey: An Up-to-date Survey of the Theory." Athens Journal of Mediterranean Studies 3(2):163-186.

\section{Bio}

Arduino Maiuri, Ph.D. in Greek \& Latin philology, religious history and history, antropology, religions; post-doc, Sapienza University of Rome, Italy; research fields: ancient Rome, Latin literature, Roman law, religious history, symbology of caves, clothing in ancient world, teratology. 